\title{
Pengaruh Pengungkapan Corporate Social Responsibility, Leverage, Dan Kepemilikan Manajerial Terhadap Agresivitas Pajak
}

\author{
Denny Wijaya ${ }^{1}$, Akhmad Saebani ${ }^{2}$ \\ ${ }^{1,2}$ Universitas Pembangunan Nasional Veteran Jakarta, Jl. R.S. Fatmawati No. 1, Jakarta \\ ${ }^{1}$ dennywijaya1296@gmail.com, ${ }^{2}$ a.saebani@gmail.com
}

\begin{abstract}
This research is using quantitative study aimed to see whether there are influences of Corporate Social Responsibility Disclosure, Leverage, and Managerial Ownership on Tax Aggressiveness. In this research, tax aggressiveness is measured using Cash Effective Tax Rates, corporate social responsibility disclosure is measured using Corporate Social Responsibility Index, leverage is measured using Debt to Total Assets, and Managerial Ownership is measured using dummy variable. This research uses consumer goods industry sector in manufacturing companies listed in Indonesia Stock Exchange for the 2015-2017 financial year. Number of observation of 81 samples obtained through non-probability sampling method is purposive sampling method. Testing the hypothesis in this study was used Multiple Linear Regression Analysis using SPSS 25 analysis tool with a significant level of 5\% (0,05). The results of these tests indicate that (1) corporate social responsibility disclosure has a positive significant influence on tax aggressiveness, (2) leverage has no significant influence on tax aggressiveness, (3) managerial ownership has a negative influence on tax aggressiveness

Keywords : Tax Aggressiveness, Corporate Social Responsibility Disclosure, Leverage, Managerial Ownership
\end{abstract}

\section{PENDAHULUAN}

Pajak memegang peranan penting dalam perekonomian Indonesia. Hal ini dikarenakan pajak merupakan sumber pendapatan utama negara. Pentingnya peranan pajak bagi negara menyebabkan pemerintah menciptakan berbagai program dan regulasi yang ditujukan untuk meningkatkan penerimaan dari sektor pajak. Adapun usaha yang dilakukan pemerintah untuk meningkatkan penerimaan dari sektor pajak adalah memberikan insentif penurunan tarif pajak badan melalui Undang-Undang Nomor 36 Tahun 2008 Pasal 17 ayat (2b) dan Peraturan Pemerintah Nomor 46 Tahun 2013 tentang penyederhanaan perhitungan pajak. Namun dalam kenyataannya, program dan regulasi yang diciptakan oleh pemerintah ini banyak disalahgunakan. Hal ini mendorong perusahaan melakukan tindakan untuk meminimalisir beban pajaknya legal maupun ilegal dengan cara melakukan agresivitas pajak.

Menurut Frank et al (2009), agresivitas pajak merupakan suatu tindakan merekayasa pendapatan kena pajak perusahaan yang dilakukan melalui tindakan perencanaan pajak, baik menggunakan cara yang tergolong secara legal (tax avoidance) maupun yang tergolong secara ilegal (tax evasion). Terdapat banyak faktor yang dapat mempengaruhi suatu perusahaan dalam melakukan tindakan agresivitas pajak. Beberapa diantaranya adalah Pengungkapan Corporate Social Responsibility, Leverage, dan Kepemilikan Manajerial. Dalam sudut pandang perusahaan, pajak dapat menjadi faktor motivasi dalam merancang keputusan perusahaan (Jessica dan Toly, 2014). Banyak tindakan manajerial perusahaan yang dirancang hanya untuk meminimalkan pajak perusahaan dalam bentuk agresivitas pajak dan telah menjadi hal umum dalam dunia perusahaan (Lanis and Richardson, 2012).

Selama tidak melanggar UndangUndang yang berlaku, tindakan agresivitas pajak ini tentu saja memberikan keuntungan bagi perusahaan. Salah satunya adalah menurunnya kewajiban pajak perusahaan guna memperoleh laba dan likuiditas yang diharapkan manajemen (Rohman dan Pradnyadari, 2015). Namun 
dibalik itu, tindakan agresivitas pajak yang dilakukan perusahaan dipandang oleh masyarakat sebagai tindakan yang tidak bertanggung jawab. Pembayaran pajak yang dilakukan oleh perusahaan dianggap oleh masyarakat luas sebagai kontribusi perusahaan dalam membangun kesejahteraan masyarakat melalui penyediaan, pembangunan, pengembangan dan pemeliharaan fasilitas-fasilitas publik yang dilakukan oleh pemerintah. Hal ini dapat mengubah persepsi masyarakat terhadap perusahaan menjadi negatif, dimana perusahaan tersebut dianggap tidak menjalankan Corporate Social Responsibility dengan baik (Ratmono dan Sagala, 2015).

Tabel 1. Realisasi Penerimaan Pajak Indonesia Tahun 2012-2016

\begin{tabular}{cccc}
\hline \multirow{2}{*}{ Tahun } & \multicolumn{2}{c}{ Penerimaan Pajak } & \multirow{2}{*}{ Pencapaian Target } \\
\cline { 2 - 3 } & Target & Realisasi & \\
\hline $\mathbf{2 0 1 2}$ & 885,03 Triliun & 835,83 Triliun & $94,40 \%$ \\
\hline $\mathbf{2 0 1 3}$ & 995,21 Triliun & 921,39 Triliun & $92,58 \%$ \\
\hline $\mathbf{2 0 1 4}$ & $1.072,38$ Triliun & 985,13 Triliun & $91,86 \%$ \\
\hline $\mathbf{2 0 1 5}$ & $1.294,25$ Triliun & $1.060,86$ Triliun & $81,97 \%$ \\
\hline $\mathbf{2 0 1 6}$ & $1.355,20$ Triliun & $1.104,90$ Trilun & $81,40 \%$ \\
\hline
\end{tabular}

Dengan melihat Tabel 1 diatas terkait dengan informasi yang dikeluarkan oleh Kementerian Keuangan Republik Indonesia dalam Media Keuangan Volume XII Nomor 114 mengenai realisasi penerimaan pajak Indonesia tahun 20122016, penerimaan pajak memang mengalami peningkatan selama lima tahun berturut-turut yaitu ditahun 2012-2016, tetapi bukan berarti penerimaan pajak mencapai target yang telah ditetapkan. Faktanya, penerimaan pajak tahun 20122016 tidak mencapai target yang telah ditetapkan bahkan persentase realisasi penerimaan pajaknya cenderung menurun. Hal ini menandakan bahwa pemerintah gagal untuk mencapai target pajak pada tahun-tahun yang bersangkutan.

Selain itu, Tax Ratio suatu negara dipandang dapat menggambarkan tingkat agresivitas pajak dan tingkat kepatuhan pajak perusahaan-perusahaan yang beroperasi di dalam suatu negara. Berdasarkan informasi yang dikeluarkan oleh Kementerian Keuangan Republik Indonesia dalam APBN 2018, Tax Ratio Indonesia tahun 2013 sebesar 14,3\%, tahun 2014 sebesar 13,7\%, tahun 2015 sebesar $11,6 \%$, tahun 2016 sebesar 10,6\%, dan tahun 2017 sebesar 11,5\%. Hal ini menggambarkan bahwa Tax Ratio Indonesia terus mengalami penurunan dari tahun 2013-2016 sedangkan baru mengalami peningkatan pada tahun 2017. Walaupun mengalami peningkatan, Tax Ratio Indonesia masih berada pada persentase $11,5 \%$ yang artinya masih berada dibawah standar negara-negara Association of South East Asia Nations (ASEAN) dan Organisation on Economic Cooperation and Development (OECD).

Menurut Airlangga Hartanto (2018) selaku Menteri Perindustrian, kontribusi penerimaan pajak industri manufaktur terus meningkat dari tahun 2014 sampai dengan tahun 2017 sehingga mengantarkan industri manufaktur sebagai penyumbang pajak terbesar dalam beberapa tahun terakhir. Sepanjang tahun 2017 sektor manufaktur tercatat tumbuh sebesar 17,1 persen, dimana industri tersebut menjadi kontributor tertinggi terhadap penerimaan PPh Non Migas yaitu 31,8 persen dari total keseluruhan PPh Non Migas diikuti oleh sektor perdagangan sebesar 19,3 persen, jasa keuangan sebesar 14 persen, dan pertanian sebesar 17 persen. Namun hal ini tidak mendorong peningkatan yang signifikan terhadap Tax Ratio Indonesia, Tax Ratio Indonesia masih berada di bawah standar negara-negara ASEAN. Selain itu, berdasarkan Laporan Kinerja Direktorat Jenderal Pajak tahun 2016 khususnya pada $\mathrm{PPh}$ pasal 25/29 Badan, jumlah penerimaan 
pajak dari $\mathrm{PPh}$ pasal 25/29 Badan tahun 2016 mengalami penurunan dibandingkan dengan tahun sebelumnya. Pada tahun 2015, Direktorat Jenderal Pajak menerima total jumlah pajak dari jenis pajak $\mathrm{PPh}$ pasal 25/29 Badan sebesar Rp 185,20 Triliun namun di tahun 2016 hanya menerima total jumlah pajak dari PPh 25/29 Badan sebesar Rp 172,01 Triliun. Artinya penerimaan jenis pajak PPh 25/29 Badan mengalami penurunan sebesar 13,19 Triliun. Yang mana penerimaan $\mathrm{PPh}$ 25/29 Badan pada tahun 2016 didominasi oleh industri manufaktur.

Indikasi kasus agresivitas pajak yang dilakukan oleh industri manufaktur di Indonesia telah terjadi beberapa kali. Salah satunya adalah PT. Coca Cola Indonesia (CCI) yang termasuk dalam kelompok Coca Cola Company. Menurut Edward Sianipar (2014) selaku perwakilan Direktorat Jenderal Pajak, menyatakan bahwa tahun 2014 PT. Coca Cola Indonesia terindikasi melakukan penghindaran pajak senilai Rp 49,24 Milyar. Kasus ini terjadi untuk tahun pajak 2002, 2003, 2004, dan 2006, dimana berdasarkan hasil penelusuran Direktorat Jenderal Pajak, Kementerian Keuangan menemukan ada pembengkakan biaya yang besar pada tahun-tahun tersebut. Beban biaya ini antara lain adalah beban iklan produk Coca Cola dalam rentang waktu 2002-2006. Hal ini berdampak pada penurunan penghasilan kena pajak PT. Coca Cola Indonesia sebesar Rp 49,24 Miliar dikarenakan adanya perbedaan hasil perhitungan penghasilan kena pajak yang dilakukan oleh Direktorat Jenderal Pajak dengan PT Coca Cola Indonesia. Hal ini menunjukkan bahwa masih adanya tindakan agresivitas pajak yang dilakukan oleh perusahaanperusahaan yang ada di Indonesia.

Dalam konteks pembangunan, keberhasilan suatu perusahaan tidak hanya diukur dari keuntungan bisnis perusahaan, melainkan juga dilihat dari sejauh mana kepeduliaan perusahaan terhadap aspek sosial dan lingkungan atau yang dikenal dengan Corporate Social Responsibility.
Corporate Social Responsibility merupakan bentuk tanggung jawab perusahaan kepada semua stakeholder-nya dan pajak merupakan salah satu bentuk tanggung jawab sosial perusahaan kepada salah satu stakeholder-nya yaitu pemerintah. Perusahaan yang melakukan tindakan agresivitas pajak dipandang sebagai perusahaan yang tidak bertanggung jawab secara sosial (Lanis dan Richardson, 2012). Namun disisi lain, banyak perusahaan yang menjadikan kegiatan pertanggungjawaban sosialnya sebagai upaya untuk memanipulasi pajak dengan dalih peningkatan kondisi lingkungan, peningkatan kapasitas SDM, peningkatan kesejahteraan para pekerja, pemberdayaan ekonomi lokal, dan rehabilitasi lingkungan (Mumtahanah dan Septiani, 2017).

Leverage suatu perusahaan juga dapat dikaitkan dengan agresivitas pajak. Leverage merupakan rasio yang menunjukkan besarnya modal eksternal yang digunakan untuk membiayai aktivitas operasinya. Apabila perusahaan memiliki sumber dana pinjaman tinggi, maka perusahaan akan membayar beban bunga yang tinggi kepada kreditur. Dimana beban bunga merupakan pengurang laba tahun berjalan yang akan berdampak pada pengurangan beban pajak dalam satu periode berjalan (Brigham dan Houston, 2010 hlm.141). Namun apabila dihubungkan dengan Debt Covenant Hypothesis, perusahaan yang memiliki tingkat leverage tinggi akan cenderung untuk mempertahankan laba periode berjalan dikarenakan perusahaan harus membayar beban bunga yang timbul dan juga mendapatkan pengawasan dari pihak kreditur. Hal ini akan mempengaruhi beban pajak perusahaan dimana perusahaan akan tidak agresif terhadap pajak.

Selain itu juga, kepemilikan manajerial dipandang sebagai salah satu faktor yang dapat mempengaruhi agresivitas pajak. Kepemilikan manajerial merupakan kepemilikan saham oleh pihak manajemen, dimana pihak manajemen secara aktif ikut terlibat dalam pengambilan 
keputusan perusahaan (Fadhila dkk, 2017). Kepemilikan manajerial ikut mempengaruhi keputusan perusahaan, salah satunya adalah keputusan perpajakan. Umumnya pihak manajemen akan cenderung untuk mempertahankan kelangsungan perusahaan melalui penciptaan laba, dimana hal ini akan berdampak pada beban pajak perusahaan yang semakin tinggi. Namun di sisi lain, kepemilikan manajerial bisa juga menjadi motivasi dalam melakukan tindakan agresivitas pajak sebagai upaya penghematan pajak perusahaan.

Berangkat dari fenomena diatas terhadap agresivitas pajak, beberapa peneliti telah melakukan penelitian terhadap agresivitas pajak. Penelitian-penelitian tersebut menghasilkan ketidakkonsistenan (inkonsistensi) hasil penelitian. Penelitian Mumtahanah dan Septiani (2017) menemukan bahwa pengaruh Pengungkapan Corporate Social Responsibility terhadap Agresivitas Pajak adalah berpengaruh positif, sedangkan penelitian Lanis dan Richardson (2012) dan Ratmono dan Sagala (2015) menemukan bahwa pengaruh Pengungkapan Corporate Social Responsibility terhadap Agresivitas Pajak adalah berpengaruh negatif. Namun, penelitian Jessica dan Toly (2014) menunjukkan hasil sebaliknya bahwa Pengungkapan Corporates Social Responsibility terhadap Agresivitas Pajak adalah tidak berpengaruh signifikan. Penelitian tentang pengaruh Leverage terhadap Agresivitas pajak juga telah dilakukan oleh beberapa peneliti dan menghasilkan hasil penelitian yang tidak konsisten. Penelitian Fadli (2016) dan Suyanto dan Supramono (2017) menemukan bahwa pengaruh Leverage terhadap Agresivitas Pajak adalah berpengaruh positif, sedangkan penelitian Andhari dan Sukartha (2017) dan Dharma dan Ardiana (2016) menemukan bahwa pengaruh Leverage terhadap Agresivitas Pajak adalah berpengaruh negatif. Namun penelitian Adisamartha dan Noviari (2015) dan Hartadinata dan Tjaraka (2013) menunjukkan hasil sebaliknya bahwa pengaruh Leverage terhadap Agresivitas Pajak adalah tidak berpengaruh signifikan. Selain itu, penelitian tentang pengaruh Kepemilikan Manajerial terhadap Agresivitas pajak juga telah dilakukan oleh beberapa peneliti dan menghasilkan hasil penelitian yang tidak konsisten. Penelitian Atari (2016) menemukan bahwa pengaruh Kepemilikan Manajerial terhadap Agresivitas Pajak adalah berpengaruh positif, sedangkan penelitian Fadhila dkk (2017) dan Pramudito dan Sari (2015) menemukan bahwa pengaruh Kepemilikan Manajerial terhadap Agresivitas Pajak adalah berpengaruh negatif. Namun penelitian Novitasari (2017) dan Prasetyo dan Pramuka (2018) menunjukkan hasil sebaliknya bahwa pengaruh Kepemilikan Manajerial terhadap Agresivitas Pajak adalah tidak berpengaruh signifikan.

Adapun perbedaan rencana penelitian adalah perbedaan jenjang waktu penelitian yaitu penelitian ini akan menggunakan periode tahun 2015-2017, perbedaaan sampel yang akan digunakan di dalam penelitian, dan penggunaan standar Global Reporting Initiative Generasi ke-4 sebagai proksi dari pengungkapan Corporate Social Responsibility dalam penelitian yang akan dilaksanakan. Berlatar belakang dari fenomena dan inkonsistensi hasil dari penelitian, maka peneliti tertarik untuk meneliti dan menguji kembali pengaruh Pengungkapan Corporate Social Responsibility, Leverage, dan Kepemilikan Manajerial terhadap Agresivitas Pajak.

Berdasarkan ulasan tersebut, rumusan masalah penelitian adalah apakah Pengungkapan Corporate Social Responsibility berpengaruh signifikan terhadap Agresivitas Pajak, apakah Leverage berpengaruh signifikan terhadap Agresivitas Pajak, apakah Kepemilikan Manajerial berpengaruh terhadap Agresivitas Pajak. Maka dari itu, tujuan penelitian dalam penelitian ini adalah menguji secara empiris pengaruh Pengungkapan Corporate Social Responsibility terhadap Agresivitas Pajak, 
pengaruh Leverage terhadap Agresivitas Pajak, dan pengaruh Kepemilikan Manajerial terhadap Agresivitas Pajak.

\section{TELAAH LITERATUR Teori Legitimasi}

Pada umumnya organisasi berusaha untuk menciptakan sebuah sistem nilai perusahaan yang dapat berjalan sesuai dengan sistem nilai sosial yang lebih besar dimana organisasi tersebut merupakan bagian dari sistem tersebut. Hal ini bertujuan agar organisasi tersebut mendapatkan legitimasi dari masyarakat guna mempertahankan kelangsungan hidupnya. Menurut Dowling dan Pfeffer (1975), teori legitimasi didasarkan pada adanya fenomena kontak sosial antara sebuah organisasi dan masyarakat, dimana tujuan organisasi harus selaras dengan nilai-nilai yang ada didalam sebuah masyarakat Salah satu bentuk legitimasi yang dilakukan oleh organisasi adalah aktivitas tanggung jawab sosial atau yang sering disebut dengan Corporate Social Responsibility (Ratmono dan Sagala, 2015). Menurut Prasista dan Setiawan (2016), teori legitimasi merupakan teori yang menjelaskan bahwa pengungkapan tanggung jawab sosial perusahaan dilakukan untuk mendapatkan legitimasi dari masyarakat dimana perusahaan berada sehingga perusahaan dapat menjalankan kegiatan usahanya. Perusahaan secara tidak langsung mempunyai kontrak dengan masyarakat untuk melakukan kegiatankegiatannya berdasarkan nilai-nilai keadilan (justice) yang berkembang di masyarakat. Teori ini juga menyatakan bahwa perusahaan bukan hanya memperhatikan hak-hak investor tetapi juga memperhatikan hak-hak publik sebagai salah satu tanggung jawabnya. Selain itu, legitimasi sosial dipandang sebagai hal yang sangat diinginkan oleh perusahaan guna meningkatkan kekuatan keuangannya secara maksimal untuk jangka waktu panjang melalui respon positif yang diterima perusahaan dari masyarakat dan para pelaku pasar saham (Rengganis dan Putri, 2018).

\section{Teori Keagenan}

Menurut Jensen and Meckling (1976), Teori Keagenan atau Agency Theory diartikan sebagai teori yang terkait dengan kontrak dimana satu atau beberapa orang (principal) mempekerjakan orang lain (agent) untuk melaksanakan sejumlah jasa dan mendelegasikan wewenang untuk mengambil keputusan kepada agen tersebut. Menurut Ross et al (2016, hlm.10), teori keagenan menjelaskan hubungan yang terjadi antara pemegang saham dengan manajemen, dimana pemegang saham sebagai principal mempekerjakan orang lain sebagai manajemen (agent) yang bertindak untuk mewakili kepentingannya. Hubungan yang terjadi antara pemegang saham (principal) dengan manajemen (agent) ini disebut sebagai Agency Relationship sedangkan konflik kepentingan yang mungkin terjadi antara pemegang saham (principal) dengan manajemen (agent) disebut sebagai Agency Problem.

\section{Teori Akuntansi Positif}

Menurut Andhari dan Sukartha (2017), teori akuntansi positif menjelaskan perilaku manajemen dalam melaksanakan pembuatan laporan keuangan. Teori ini memberikan kebebasan kepada manajemen untuk memilih alternatif dari beberapa prosedur akuntansi yang ada dengan tujuan meminimalisir biaya kontrak dan meningkatkan nilai perusahaan (Adisamartha dan Noviari, 2015). Pihak manajemen diberi kebebasan untuk memilih prosedur-prosedur akuntansi yang relevan dengan mengikuti standar-standar akuntansi yang terus mengalami perkembangan dari masa ke masa.

Menurut Watts and Zimmerman (1986), terdapat tiga hipotesis yang dikembangkan terkait dengan teori akuntansi positif:

- $\quad$ The Debt Covenant Hypothesis

Apabila perusahaan mempunyai rasio antara utang dan ekuitas yang besar, maka 
manajer di dalam perusahaan akan cenderung memilih dan menggunakan metode-metode akuntansi yang akan membuat laba periode berjalan yang dilaporkan menjadi lebih tinggi (Scott, 2012 hlm.307). Menurut Adisamartha dan Noviari (2015), semakin tingginya hubungan perusahaan dengan pihak ketiga (kreditur) maka perusahaan akan lebih menjaga laba periode berjalan guna menjaga stabilitas kinerja perusahaan. Hal ini terjadi karena semakin tinggi kepentingan perusahaan terhadap kreditur maka semakin tinggi pula pengawasan yang dilakukan oleh kreditur dalam rangka memastikan kelangsungan pinjaman modal

\section{- $\quad$ The Bonus Plan Hypothesis}

Pihak manajer di dalam perusahaan cenderung memilih dan menggunakan metode-metode akuntansi yang akan membuat laba periode berjalan yang dilaporkan menjadi lebih tinggi. Apabila kompenasi atau bonus ditentukan oleh laba periode berjalan yang dilaporkan, maka manajer perusahaan akan berusaha untuk meningkatkan laba periode berjalan semaksimal mungkin. Salah satunya adalah dengan memilih kebijakan akuntansi yang tepat dan relevan dalam meningkat laba periode berjalan. Hal ini terjadi karena manajer akan cenderung berorientasi terhadap bonus atau kompensasi manajerial (Scott, 2003 hlm.307).

\section{- $\quad$ The Political Cost Hypothesis}

Semakin besar perusahaan, maka semakin besar kemungkinan perusahaan tersebut untuk memilih metode akuntansi yang bertujuan untuk menurunkan laba (Scott, 2003 hlm.308). Hal ini dilandaskan oleh alasan bahwa laba yang tinggi akan mendorong pemerintah untuk segera mengambil tindakan terkait dengan kebijakan kenaikan pajak pendapatan sehingga perusahaan akan berusaha menurunkan labanya guna menekan besaran pajak pendapatannya.

\section{Agresivitas Pajak}

Agresivitas pajak merupakan keinginan dan tindakan meminimalkan beban pajak dengan cara legal, ilegal, atau keduanya (Lanis and Richardson, 2012). Selain itu, Frank et al (2009) mendefinisikan agresivitas pajak sebagai suatu tindakan yang dirancang guna mengurangi penghasilan kena pajak perusahaan melalui tindakan perencanaan pajak (tax planning) baik dengan menggunakan cara yang tergolong legal yaitu penghindaran pajak (tax avoidance) maupun cara yang tergolong ilegal yaitu penggelapan pajak (tax evasion). Tindakan agresivitas pajak dapat terbagi menjadi dua, yaitu:

\section{- Penghindaran Pajak}

Menurut Sumarsan (2012, hlm.118), penghindaran pajak adalah tindakan yang dirancang dimana wajib pajak tidak secara jelas melanggar undang-undang meskipun terkadang dengan menafsirkan undangundang yang tidak sesuai dengan maksud dan tujuan pembuat undang-undang.

\section{- Penggelapan Pajak}

Penggelapan pajak adalah tindakan perlawanan pajak dalam bentuk perlawanan terhadap undang-undang yang berlaku dengan maksud melepaskan diri dari pajak atau mengurangi dasar penetapan pajak dengan cara menyembunyikan sebagian dari penghasilannya.

Tindakan agresivitas pajak yang dilakukan perusahaan dapat memberikan marginal benefit dan marginal cost bagi perusahaan (Fahriani dan Priyadi, 2016). Marginal benefit yang mungkin saja diperoleh perusahaan dari tindakan agresivitas pajak adalah adanya penghematan pajak (tax saving) yang signifikan bagi perusahaan, manajer juga bisa mendapatkan kompensasi yang lebih tinggi atas kinerjanya yang baik dalam hal penghematan pajak serta keuntungan pribadi dengan menyusun laporan keuangan yang agresif atau dikenal dengan rent extraction. Selain itu, marginal cost juga dapat ditanggung oleh perusahaan akibat tindakan agresivitas pajaknya. Marginal cost yang mungkin saja terjadi adalah penalty atau sanksi administrasi yang dikenakan oleh petugas pajak akibat 
dilakukannya audit terhadap perusahaan dan ditemukannya kecurangan-kecurangan dibidang perpajakan pada perusahaan.

\section{Pengungkapan Corporate Social Responsibility}

Menurut World Bank, Corporate Social Responsibility didefinisikan sebagai komitmen perusahaan untuk berkontribusi terhadap kinerja pembangunan ekonomi yang berkelanjutan dengan karyawan dan perwakilan mereka dalam komunitas setempat serta masyarakat secara luas guna meningkatkan kualitas hidup, dengan cara yang baik untuk dunia usaha dan juga untuk pembangunan. Corporate Social Responsibility juga dapat diartikan bagaimana suatu perusahaan memperhitungkan dampak sosial dan lingkungan dalam melaksanakan aktivitas operasi perusahaan, yakni memaksimalkan manfaat dan meminimalkan kerugian (Lanis dan Richardson, 2012). John Elkington (1997) dalam Busyra Azheri (2011, hlm.25) menjelaskan bahwa CSR lebih menekankan sejauh mana suatu perusahaan mengindahkan kewajibannya terhadap konsumen, karyawan, pemegang saham, masyarakat, dan ekologis dalam semua aspek aktivitasnya. Berkaitan dengan hal ini, CSR dikelompokkan menjadi tiga aspek yang dikenal dengan Triple Bottom Line (3BL) yaitu kesejahteraan atau kemakmuran ekonomi (Economic Prosperity), peningkatan kualitas lingkungan (Environmental Quality), dan keadilan sosial (Social Justice).

Menurut Ratmono dan Sagala (2015), pengungkapan CSR merupakan proses penyediaan dan pengkomunikasian informasi terkait dengan dampak sosial dan lingkungan dari kegiatan ekonomi yang dilakukan perusahaan terhadap pihak-pihak yang berkepentingan terutama masyarakat secara luas. Penerapan dan pengungkapan Corporate Social Responsibility dapat memberikan nilai tambah bagi perusahaan meskipun perusahaan yang mengabaikan persoalan sosial, ekonomi, dan lingkungan dalam kegiatan usahanya masih tetap dapat memperoleh keuntungan. Tetapi untuk jangka panjang, perusahaan akan mengalami kesulitan untuk mempertahankan eksistensinya (Azheri, 2011 hlm.128). Dalam Undang-Undang Nomor 40 Tahun 2007 pasal 66 ayat 2c dijelaskan bahwa semua perseroan diharuskan melaporkan pelaksanaan tanggung jawab sosial dan lingkungan dalam laporan tahunan. Ketentuan mengenai pengungkapan Corporate Social Responsibility di Indonesia menggunakan konsep dari Global Reporting Initiative (GRI) sebagai acuan dalam proses penyusunan pelaporan CSR serta pengungkapan tanggung jawab sosial dan lingkungan didalam laporan tahunan. Pada tahun 2013, khususnya di Indonesia, GRIG3 mengalami perkembangan menjadi GRI-G4 sebagai standar pengungkapan. GRI-G4 merupakan pembaruan dari generasi sebelumnya yang memberikan penekanan terhadap kebutuhan organisasi tentang fokus dalam proses pelaporan dan laporan final yang berisi topik-topik yang material bagi bisnis dan pemangku kepentingan mereka. Dalam pedoman GRIG4, terdapat beberapa kategori pengungkapan yaitu Ekonomi, Lingkungan, dan Sosial dengan 91 item indikator pengungkapan.

\section{Leverage}

Leverage merupakan rasio yang menunjukkan besarnya modal pinjaman eksternal yang digunakan perusahaan untuk melakukan aktivitas operasinya (Adisamartha dan Noviari, 2015). Rasio Leverage menandakan seberapa besar aset yang dimiliki perusahaan berasal dari modal pinjaman perusahaan. Selain itu, rasio leverage menunjukkan besarnya utang yang dimiliki oleh perusahaan untuk membayai aktivitas operasinya, dimana dalam penggunaannya menimbulkan biaya tetap bagi perusahaan (Mayangsari, 2015). Apabila perusahaan memiliki sumber dana pinjaman tinggi, maka perusahaan akan menimbulkan beban bunga yang tinggi 
kepada kreditur. Leverage terbagi menjadi dua yaitu:

\section{- $\quad$ Operating Leverage}

Operating Leverage adalah penggunaan aktiva yang menyebabkan perusahaan harus menanggung biaya operasi tetap. Semakin tinggi operating leverage perusahaan, semakin besar laba akan berubah mengikuti persentase perubahan dari penjualan (Keown et al, 2017 hlm.438).

\section{- Financing Leverage}

Financial Leverage adalah pembiayaan sebagian aset perusahaan dilakukan dengan sekuritas yang mengandung tingkat pengembalian tetap (berupa bunga) dengan tujuan dalam rangka meningkatkan pengembalian kepada pemegang saham.

\section{Kepemilikan Manajerial}

Fadhila dkk (2017) mendefinisikan kepemilikan manajerial sebagai kepemilikan saham oleh manajemen yang diukur dari persentase saham biasa yang dimiliki oleh manajemen yang secara aktif terlibat dalam pengambilan keputusan perusahaan. Selain itu, kepemilikan manajerial juga didefinisikan sebagai kepemilikan saham biasa oleh insider atau pihak manajemen yang terlibat aktif dalam pengambilan keputusan di dalam perusahaan (Hartadinata dan Tjaraka, 2013). Semakin besar proporsi kepemilikan saham manajerial di dalam perusahaan, maka pihak manajemen cenderung lebih giat untuk memperhatikan kepentingan pemegang saham dan membuat risiko perusahaan semakin kecil. Hal ini dikarenakan apabila terdapat keputusan yang salah, manajemen baik secara langsung maupun tidak langsung akan menanggung konsekuensinya dengan saham-saham yang diinvestasikan di dalam perusahaan.

Hubungan antara pemegang saham dengan direksi/manajer perusahaan sangat rentan terhadap konflik kepentingan atau yang sering disebut dengan agency problem. Menurut Hartadinata dan Tjaraka (2013), peningkatan kepemilikan manajerial merupakan salah satu cara yang dapat digunakan oleh perusahaan untuk mengatasi agency problem. Perusahaan meningkatkan kepemilikan manajerial guna mensejajarkan kedudukan para direksi/manajer dengan para pemegang saham.

\section{HIPOTESIS}

\section{Pengaruh Pengungkapan Corporate Social Responbility Terhadap Agresivitas Pajak}

Rohman dan Pradnyadari (2015) menyatakan bahwa lingkungan dan masyarakat mempengaruhi kinerja suatu perusahaan. Corporate Social Reponsibility (CSR) merupakan salah satu bentuk hubungan komunikasi antara perusahaan dengan lingkungan masyarakat yang sesuai dengan teori legitimasi. Teori legitimasi menuntut perusahaan untuk mengungkapkan tanggung jawab sosial perusahaan dimana perusahaan dikatakan sukses melaksanakan legitimasi apabila dapat memenuhi harapan masyarakat melalui pelaksanaan tanggung jawab sosial perusahaan. Menurut teori legitimasi, pengungkapan CSR yang dilakukan perusahaan bertujuan untuk mendapatkan legitimasi/pengakuan dari masyarakat dimana perusahaan berada (Ratmono dan Sagala, 2015). Legitimasi yang diperoleh akan membuat perusahaan terhindar dari hal-hal yang tidak diinginkan sehingga akan berdampak pada peningkatan nilai perusahaan tersebut. Dalam praktiknya, perusahaan umumnya akan merasa terbebani dengan banyaknya tanggung jawab yang ada sehingga tindakan meminimalkan pajak menjadi salah satu pilihan untuk meminimalkan tanggung jawab. Namun, pada dasarnya tindakan meminimalkan pajak tidak sesuai dengan harapan masyarakat dan memiliki dampak negatif bagi masyarakat dikarenakan akan mempengaruhi kemampuan pemerintah dalam menyediakan barang publik bagi masyarakat (Lanis dan Richardson, 2012). Prasista dan Setiawan (2016) memandang bahwa apabila perusahaan peduli terhadap 
pentingnya CSR, maka perusahaan tersebut semakin peduli terhadap pentingnya peran pajak bagi masyarakat luas.

Menurut Watson (2011) dalam Rohman dan Pradnyadari (2015), tindakan agresivitas pajak yang dilakukan oleh perusahaan dapat menimbulkan sanksi sosial dari masyarakat. Masyarakat yang paham akan pentingnya Corporate Social Responsibility cenderung memboikot produk perusahaan dan enggan untuk membeli produk perusahaan sehingga berdampak pada menurunnya jumlah penjualan perusahaan yang tentu saja akan menganggu kelangsungan hidup perusahaan. Lanis dan Richardson (2012) berpendapat bahwa keputusan perusahaan dalam mengambil sikap tidak agresif terhadap perpajakan akan memberikan manfaat terhadap perusahaan, dimana perusahaan akan memperoleh legitimasi dari masyarakat sehingga dapat mempertahankan kedudukannya baik di dalam masyarakat maupun negara. Perusahaan yang telah mendapatkan citra baik dari masyarakat melalui pengungkapan CSR yang dilakukannya akan berusaha untuk mempertahankan citra baik yang dimilikinya, sedangkan perusahaan yang kurang memiliki citra baik di mata masyarakat akibat rendahnya pengungkapan CSR yang dilakukan cenderung lebih agresif agar dapat membayar pajak lebih rendah (Ratmono dan Sagala, 2015). Maka dari itu, perusahaan yang memiliki citra baik cenderung menghindari kemungkinan adanya sanksi perpajakan sebagai dampak dari tindakan agresivitas pajak yang dilakukan. Dengan demikian, semakin tinggi tingkat pengungkapan CSR maka semakin rendah tindakan agresivitas pajak yang dilakukan oleh perusahaan. Hal ini dikarenakan perusahaan yang menjalankan dan mengungkapan CSR dengan baik umumnya memiliki tindakan agresivitas pajak yang rendah.

H1:Pengungkapan Corporate Social Responsibility berpengaruh signifikan negatif terhadap Agresivitas Pajak

\section{Pengaruh Leverage Terhadap Agresivitas Pajak \\ Leverage dapat diartikan sebagai} kemampuan perusahaan untuk memenuhi kemampuan finansial jangka panjang maupun jangka pendek. Sumber dana pihak ketiga merupakan sumber dana yang cukup menjanjikan bagi perusahaan guna melakukan ekspansi dan eksplorasi dalam rangka mencari keuntungan. Tingkat leverage perusahaan menandakan bahwa perusahaan sedang mengupayakan meningkatkan labanya yang juga turut berdampak pada agresivitas pajak perusahaan (Andhari dan Sukartha, 2017). The Debt Covenant Hypothesis menyatakan bahwa apabila perusahaan mempunyai rasio antara utang dan ekuitas yang besar, maka manajer di dalam perusahaan akan cenderung memilih dan menggunakan metode-metode akuntansi yang akan membuat laba periode berjalan yang dilaporkan menjadi lebih tinggi (Scotts, 2012 hlm.307). Menurut Adisamartha dan Noviari (2015), the debt covenant hypothesis menjelaskan bahwa semakin tinggi hubungan suatu perusahaan dengan pihak ketiga (kreditur) maka perusahaan akan berusaha untuk menjaga laba periode berjalan dengan tujuan menjaga stabilitas kinerja perusahaan. Semakin tinggi kepentingan perusahaan dengan kreditur, maka semakin tinggi pula tingkat pengawasan kreditur terhadap kelangsungan pinjaman modal eksternal. Selain itu juga, hutang yang ada di dalam perusahaan memang dapat meningkatkan nilai perusahaan, namun dengan penggunaan utang yang besar akan menimbulkan risiko yang besar yang harus dihadapi perusahaan. Hal ini membuat pihak manajemen akan berhati-hati dalam mengambil keputusan atas hutang dan tidak mengambil risiko atas hutang yang tinggi, meskipun hutang akan memberikan benefit dalam bentuk beban bunga yang mengurangi pajak penghasilannya.

Menurut Hartadinata dan Tjaraka (2013), perusahaan yang memiliki tingkat leverage yang tinggi akan lebih transparan terhadap 
pelaporan hasil kinerjanya. Hal ini dikarenakan pihak kreditur akan selalu melakukan pemantauan terhadap kinerja perusahaan secara keseluruhan sehingga memaksa perusahaan sebagai debitur untuk melakukan transparansi, salah satunya adalah melaporkan kewajiban perpajakannya. Kondisi ini mengartikan bahwa partisipasi pihak kreditur dalam mengawasi kinerja perusahaan secara tidak langsung membantu pihak otoritas fiskal dalam mengawasi kewajiban perpajakannya. Perusahaan debitur akan mengupayakan kinerja yang terbaik untuk ditampilkan kepada pihak kreditur, salah satunya adalah melalui peningkatan laba yang juga akan berdampak terhadap kewajiban perpajakannya. Maka dari itu, perusahaan dengan tingkat leverage yang tinggi umumnya berusaha untuk menjaga stabilitas laba periode berjalan guna meningkatkan kepercayaan pihak kreditor dan investor. Artinya perusahaan yang memiliki tingkat leverage yang tinggi tidak akan agresif dalam hal perpajakan karena perusahaan tersebut akan cenderung mempertahankan laba tahun berjalan mereka.

H2:Leverage berpengaruh signifikan negatif terhadap Agresivitas Pajak.

\section{Pengaruh Kepemilikan Manajerial Terhadap Agresivitas Pajak}

Agency Theory adalah teori yang menggambarkan proses kontrak antara dua pihak atau lebih, dimana setiap pihak yang berada didalam kontrak berusaha untuk mendapatkan kesepakatan terbaik bagi dirinya masing-masing (Scott, 2003 hlm.298). Agency theory juga menjelaskan bahwa pihak manajemen (agent) di dalam suatu perusahaan mempunyai tanggung jawab yang besar terhadap pemilik perusahaan (principle) sehingga manajemen dituntut untuk mengoptimalkan profit perusahaan yang nantinya akan dilaporkan di dalam laporan keuangan perusahaan (Prasetyo dan Pramuka, 2018).
Dengan adanya kepemilikan saham oleh pihak manajemen di dalam perusahaan maka tindakan agresivitas pajak di perusahaan akan menurun (Pramudito dan Sari, 2015). Hal ini dikarenakan kepemilikan saham manajerial di dalam perusahaan akan cenderung membuat manajer untuk lebih mempertimbangkan kelangsungan hidup perusahaan, salah satunya adalah melalui penciptaan laba perusahaan dimana akan berdampak juga terhadap kewajiban perpajakannya. Selain itu, pihak manajemen juga akan lebih berhati-hati dalam mengambil suatu keputusan dikarenakan apabila keputusan yang diambil salah, maka pihak manajemen juga akan ikut menanggung kerugian baik secara langsung maupun tidak langsung. Sebaliknya, apabila keputusan yang diambil benar, maka manajemen juga akan merasakan manfaatnya baik secara langsung maupun tidak langsung (Novitasari, 2017).

Hartadinata dan Tjaraka (2013) menjelaskan bahwa dengan adanya kepemilikan saham manajerial, manajer perusahaan akan cenderung untuk mempertimbangkan kelangsungan usahanya sehingga tidak akan mengambil risiko terkait dengan permasalahan perpajakan. Dimana permasalahan perpajakan yang mungkin dialami perusahaan akan memberikan citra buruk baik dari negara maupun masyarakat yang tentu saja akan mempengaruhi kelangsungan hidup perusahaan. Artinya kepemilikan saham manajerial cenderung mendorong pihak manajemen untuk tidak melakukan tindakan agresivitas pajak guna mempertahankankan kelangsungan usahanya. Artinya dengan adanya kepemilikan manajerial di dalam suatu perusahaan maka tindakan agresivitas pajak yang dilakukan oleh perusahaan akan semakin rendah.

H3:Kepemilikan Manajerial berpengaruh signifikan negatif terhadap Agresivitas Pajak. 


\section{Fenomena:}

- $\quad$ Penurunan persentase realisasi penerimaan pajak tahun 2012-2016.

- Penurunan Tax Ratio Indonesia tahun 2013-2016 dan Tax Ratio Indonesia tahun 2017 masih dibawah standar negara-negara ASEAN dan OECD.

- $\quad$ Penurunan penerimaan PPh 25/29 Badan tahun 2016, dimana didominasi oleh perusahaan manufaktur.

- $\quad$ Kasus indikasi penghindaran pajak sebesar Rp 49,24 Milyar yang dilakukan oleh PT. Coca Cola Indonesia.

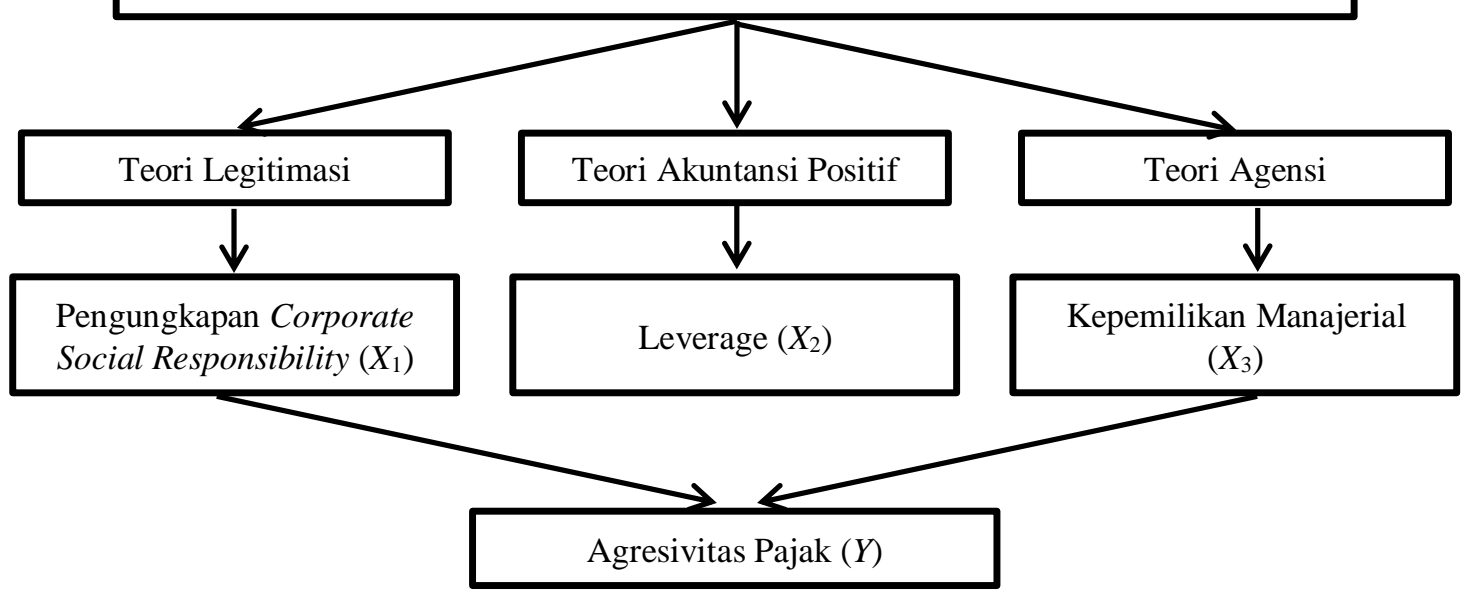

Gambar 1. Kerangka Pemikiran Penelitian

\section{METODA}

\section{Variabel Penelitian}

Agresivitas pajak secara singkat didefiniskan sebagai tindakan meminimalisir penghasilan kena pajak perusahaan melalui tindakan perencanaan pajak baik secara legal, illegal, maupun keduanya. Agresivitas pajak di dalam penelitian ini diproksikan menggunakan Cash Effective Tax Rate (CETR). Alasan peneliti memilih menggunakan CETR sebagai proksi dari agresivitas pajak adalah ETR tidak dapat memproksikan agresivitas pajak dengan baik, hal ini dikarenakan beban pajak yang menjadi pembagi laba sebelum pajak ditentukan oleh laba sebelum pajak berdasarkan pengenaan tarif tertentu dan tarif yang dikenakan adalah pasti, sedangkan CETR menggunakan pembayaran pajak dari arus kas. Adapun rumusnya:

CETR $=\frac{\text { Pembayaran Pajak }}{\text { Laba Sebelum Pajak }}$

Global Reporting Initiative merupakan sebuah kerangka pelaporan dalam menyusun laporan tahunan dan sustainability reports yang diperoleh dari https://www.globalreporting.org dimana terdiri atas prinsip-prinsip pelaporan, panduan pelaporan, dan standar pengungkapan (Andhari dan Sukartha, 2017). Standar pengungkapan ini meliputi Ekonomi (EC), Lingkungan (EN), Praktik Ketenagakerjaan dan Kenyaman Bekerja (LA), Hak Asasi Manusia (HR), Masyarakat (SO),dan Tanggung Jawab atas Produk (PR). Global Reporting Initiative Generation 4 (GRI-G4) terdiri dari 91 item pengungkapan yang disarankan sebagai indikator dalam mengungkapan pelaksanaan Corporate Social Responsibility di dalam laporan tahunan. Pengungkapan Corporate Social Responsibility dalam penelitian ini diukur dengan mencocokkan item pada daftar checklist dengan item yang diungkapkan oleh perusahaan. Apabila item CSR diungkapkan maka diberikan nilai 1 pada daftar checklist, sedangkan apabila item y tidak diungkapkan maka diberikan nilai 0 pada daftar checklist. Total hasil checklist 
dihitung untuk memperoleh jumlah item yang diungkapkan perusahaan. Adapun rumusnya:

CSRI $=\frac{\text { Jumlah item CSR yang diungkapkan perusahaan }}{91 \text { item pengungkapan yang disarankan }}$

Leverage merupakan kemampuan perusahaan untuk memenuhi kewajibannya baik itu kewajiban jangka pendek maupun jangka panjang (Andhari dan Sukartha, 2017). Leverage dalam penelitian ini diukur dengan menggunakan) rasio Debt to Total Asset Ratio (DAR) yaitu dengan membandingkan total kewajiban perusahaan dengan total aset perusahaan. Semakin besar rasio leverage maka semakin besar proporsi aset perusahaan yang dibiayai oleh hutang-hutangnya. Adapun rumusnya:

$\mathrm{LEV}=\frac{\text { Total Utang }}{\text { Total Aset }}$

Kepemilikan Manajerial merupakan kepemilikan saham oleh manajemen dimana pihak manajemen tersebut terlibat secara aktif untuk ikut dalam pengambilan keputusan perusahaan (Fadhila dkk, 2017). Kepemilikan Manajerial dalam penelitian ini diukur dengan menggunakan pengukuran yang dilakukan oleh Atari (2015) yaitu dummy variable. Adapun dummy variable yang digunakan untuk mengukur kepemilikan manajerial adalah dengan memberikan nilai 1 untuk perusahaan yang terdapat kepemilikan oleh pihak manajemen (agent) di dalam komposisi pemegang sahamnya dan nilai 0 untuk perusahaan yang tidak terdapat kepemilikan oleh pihak manajemen (agent) di dalam komposisi pemegang sahamnya.

\section{Populasi dan Sampel}

Populasi yang digunakan dalam penelitian ini adalah perusahaan manufaktur sektor industi barang konsumsi (Consumer Goods Industry) yang listing di Bursa Efek Indonesia tahun 2015-2017. Adapun alasan memilih perusahan manufaktur sebagai populasi penelitian adalah karena permasalahan yang ada di dalam perusahaan manufaktur lebih kompleks sehingga diharapkan akan lebih mampu menggambarkan keadaan perusahaan di Indonesia.

Sampel dalam penelitian ini adalah perusahaan manufaktur sektor industri barang konsumsi yang terdaftar di Bursa Efek Indonesia yang dipilih sesuai dengan kriteria tertentu (Purposive Sampling). Adapun kriteria-kriteria pengambilan sampel:

- Selama periode penelitian (20152017), perusahaan mempublikasikan laporan keuangan tahunan yang telah diaudit oleh auditor independen dan laporan tahunan (annual report). Hal ini dikarenakan peneliti menggunakan informasi yang diperoleh dari laporan keuangan tahunan dan laporan tahunan perusahaan periode 2015-2017.

- Selama periode penelitian (20152017), perusahaan tidak mengalami delisting dari Bursa Efek Indonesia. Hal ini dikarenakan perusahaan yang menjadi objek penelitian merupakan perusahaan yang terlisting di Bursa Efek Indonesia selama tahun 2015 sampai dengan tahun 2017 sehingga diharapkan akan menggambarkan kondisi perusahaan yang sesungguhnya dan dapat diperbandingkan dari tahun ke tahun.

- Selama periode penelitian (20152017), perusahaan tidak mengalami kerugian. Hal ini dikarenakan perusahaan yang mengalami rugi fiskal akan menimbulkan distorsi di dalam penelitian. Perusahaan yang mengalami kerugian umumnya tidak memiliki beban pajak penghasilan, melainkan akan memperoleh kompensasi rugi fiskal. Kompensasi tersebut akan memunculkan Deferred Tax Assets yang dapat menyebabkan Book Tax Differences.

- Perusahaan memiliki data-data yang lengkap terkait dengan variabel yang diteliti yaitu Agresivitas Pajak, Pengungkapan Corporate Social Responsibility, Leverage, dan Kepemilikan Manajerial. Hal ini 
dikarenakan perusahaan yang memiliki data-data lengkap akan mendukung hasil yang relevan dari penelitian.

\section{Teknik Analisis dan Pengujian Hipotesis}

Teknik analisis data yang digunakan adalah Analisis Regresi Berganda yang sebelumnya harus melalui Uji Asumsi Klasik meliputi Uji Normalitas, Uji Multikolonieritas, Uji Autokorelasi, dan Uji Heterokedastisitas agar data dianggap layak untuk dilanjutkan menuju analisis regresi berganda.

Dalam pengujian hipotesis, penelitian ini menggunakan analisis regresi berganda atau multiple regression. Analisis regresi berganda merupakan pengembangan dari regresi linier sederhana guna memprediksi dan mengetahui pengaruh dua atau lebih variabel bebas (independen) terhadap satu variabel tak bebas (dependen). Dalam penelitian ini, analisis regresi berganda digunakan untuk menunjukkan pengaruh pengungkapan corporate social responsibility, leverage, dan kepemilikan manajerial terhadap agresivitas pajak.

Adapun model regresi berganda yang digunakan dalam penelitian ini adalah sebagai berikut:

$Y=\alpha+\beta_{1} X_{1}+\beta_{2} X_{2}+\beta_{3} X_{3}+e$

Keterangan:

$$
\begin{aligned}
Y \quad= & \text { Agresivitas pajak perusahaan } \\
& \text { yang diukur dengan } \\
& \text { menggunakan proksi CETR } \\
& (\text { CETR }) \\
= & \text { Konstanta } \\
\alpha & =\text { Koefisien regresi } \\
\beta_{1}, \beta_{2}, \beta_{3}= & \text { Pengungkapan CSR (CSRI) } \\
X_{1} \quad= & \text { Leverage }(\mathrm{LEV}) \\
X_{2} & =\text { Kepemilikan Manajerial (KM) } \\
X_{3} \quad= & \text { Error/kesalahan } \\
e &
\end{aligned}
$$

\section{HASIL DAN PEMBAHASAN \\ Deskripsi Objek Penelitian}

Dalam penelitian ini, peneliti menggunakan data perusahaan manufaktur sektor industri barang konsumsi (Consumer Goods Industry) selama 3 tahun yaitu dari tahun 2015 sampai tahun 2017 dengan jumlah perusahaan sebanyak 50 perusahaan yang meliputi sub sektor makanan dan minuman, sub sektor rokok, sub sektor farmasi, sub sektor kosmetik dan barang keperluan rumah tangga, sub sektor peralatan rumah tangga, dan sub sektor lainnya. Data diperoleh dari website resmi Bursa Efek Indonesia yaitu www.idx.co.id, sumber lain yang relevan yaitu www.idnfinancials.com, dan website resmi masing-masing perusahaan. Penentuan sampel dalam penelitian ini menggunakan metode purposive sampling yang artinya bahwa proses pemilihan sampel didasarkan pada kriteria-kriteria yang telah ditentukan. Secara lebih rinci dijelaskan sebagai berikut:

Tabel 2. Sampel Berdasarkan Kriteria

\begin{tabular}{llc}
\hline No. & Keterangan & Jumlah \\
\hline & $\begin{array}{l}\text { Jumlah perusahaan manufaktur } \\
\text { sektor industri barang konsumsi } \\
\text { yang terdaftar di Bursa Efek }\end{array}$ & 50 \\
& \\
Indonesia. & \\
& $\begin{array}{l}\text { Jumlah perusahaan manufaktur } \\
\text { sektor industri barang konsumsi } \\
\text { yang tidak mempublikasikan } \\
\text { laporan keuangan audited dan } \\
\text { laporan tahunan selama periode } \\
\text { 2015-2017. }\end{array}$ & \\
\hline & Jumlah perusahaan manufaktur \\
sektor industri barang konsumsi \\
yang delisting selama periode \\
2015-2017.
\end{tabular}

\section{Analisis Statistik Deskriptif}

Data mengenai statistik deskriptif Agresivitas Pajak, Pengungkapan Corporate Social Responsibility, Leverage, dan Kepemilikan Manajerial ditampilkan 
dalam Tabel 3. Berdasarkan Tabel 3, Nilai minimum agresivitas pajak adalah sebesar $0,0713(7,13 \%)$ yang terdapat pada PT. Kino Indonesia Tbk tahun 2015. Sementara itu, nilai maksimun agresivitas pajak adalah sebesar $0,7238 \quad(72,38 \%)$ yang terdapat pada PT. Tempo Scan Pasific Tbk tahun 2017. Nilai mean agresivitas pajak adalah sebesar 0,289601. Artinya perusahaan manufaktur sektor industri barang konsumsi rata-rata melakukan pembayaran pajak sekitar $28,96 \%$ dari laba sebelum pajaknya. Nilai standar deviasi agresivitas pajak adalah sebesar 0,1240483 . Hal ini menunjukkan bahwa data agresivitas pajak menyimpang sebesar 0,1240483 dari rata-ratanya yang sebesar 0,289601 .

Nilai minimum pengungkapan corporate social responsibility terdapat pada PT. Tempo Scan Pasific Tbk tahun 2016 yaitu sebesar $0,0440(4,40 \%)$ atau sebanyak 4 item pengungkapan CSR yang diungkapkan. Sementara itu, nilai maksimun pengungkapan corporate social responsibility terdapat pada PT. Indofood Sukses Makmur Tbk tahun 2017 yaitu sebesar 0,3077 (30,77\%) atau sebanyak 28 item pengungkapan CSR yang diungkapkan. Nilai mean pengungkapan corporate social responsibility adalah sebesar 0,164971. Artinya perusahaanperusahaan yang menjadi sampel penelitian rata-rata mengungkapkan 15 item pengungkapan CSR di dalam laporan tahunannya. Nilai standar deviasi pengungkapan corporate social responsibility sebesar 0,0633537 . Hal ini menunjukkan bahwa data pengungkapan Corporate Social Responsibility menyimpang sebesar 0,0633537 dari rataratanya yang sebesar 0,164971. Nilai minimum leverage adalah sebesar 0,0707 $(7,07 \%)$ yang terdapat pada PT. Indusri Jamu dan Farmasi Sido Muncul Tbk tahun 2015. Sementara itu, nilai maksimun leverage adalah sebesar 0,7264 (72,64\%) yang terdapat pada PT. Unilever Indonesia Tbk tahun 2017. Nilai mean leverage adalah sebesar 0,377062. Artinya hutang perusahaan manufaktur sektor industri barang konsumsi rata-rata membiayai aset perusahaan sebesar $37,7 \%$ dari seluruh aset perusahaan.

Nilai standar deviasi pengungkapan leverage sebesar 0,1688018. Hal ini menunjukkan bahwa data pengungkapan leverage menyimpang sebesar 0,1688018 dari rata-ratanya sebesar 0,377062 . Variabel agresivitas pajak, pengungkapan corporate social responsibility, dan leverage memiliki nilai mean yang lebih besar daripada standar deviasinya artinya tidak terjadi simpangan baku yang melebihi rata-rata dan data dikatakan baik.

Tabel 3. Statistik Deskriptif Agresivitas Pajak Pengungkapan CSR, dan Leverage

\begin{tabular}{lccccc}
\hline & N & Minimun & Maximun & Mean & Std. Deviation \\
\hline CETR & 81 & 0,0713 & 0,7238 & 0,289601 & 0,1240483 \\
\hline CSRI & 81 & 0,0440 & 0,3077 & 0,164971 & 0,0633537 \\
\hline LEV & 81 & 0,0707 & 0,7264 & 0,377062 & 0,1688018 \\
\hline
\end{tabular}

Berdasarkan Tabel 4, hasil olah data SPSS memperlihatkan frekuensi bahwa sebanyak $37 \%$ atau 30 kali perusahaan tidak terdapat kepemilikan manajerial di dalam komposisi pemegang sahamnya artinya 30 data perusahaan yang menjadi data penelitian tidak terdapat kepemilikan saham oleh pihak manajemen (agent). Sedangkan sebanyak $63 \%$ atau 51 kali perusahaan terdapat kepemilikan manajerial di dalam komposisi pemegang sahamnya artinya 51 data perusahaan yang menjadi data penelitian terdapat kepemilikan saham oleh pihak manajemen (agent). Hal ini menunjukkan bahwa sebagian besar perusahaan manufaktur industri barang konsumsi memiliki kepemilikan saham oleh pihak manajemen di dalam komposisi pemegang sahamnya. 
Tabel 4. Statistik Deskriptif Kepemilikan Manajerial

\begin{tabular}{ccccc}
\hline & Frequency & Percent & Valid Percent & Cumulative Percent \\
\hline $\mathbf{0}$ & 30 & 37,0 & 37,0 & 37,0 \\
\hline $\mathbf{1}$ & 51 & 63,0 & 63,0 & 100,0 \\
\hline Total & & 100,0 & 100,0 & \\
\hline
\end{tabular}

\section{Uji Asumsi Klasik}

Penelitian ini menggunakan uji asumsi klasik untuk mengetahui hasil dari uji normalitas, autokorelasi, multikolonieritas, dan heterokedastisitas. Hal ini dilakukan guna memastikan bahwa sampel yang digunakan dalam penelitian ini terbebas atau tidak mengalami gangguan normalitas, autokorelasi, multikolonieritas, dan heterokedastisitas.

\section{Uji Normalitas}

Berdasarkan Gambar 2, grafik histogram memberikan pola distribusi yang
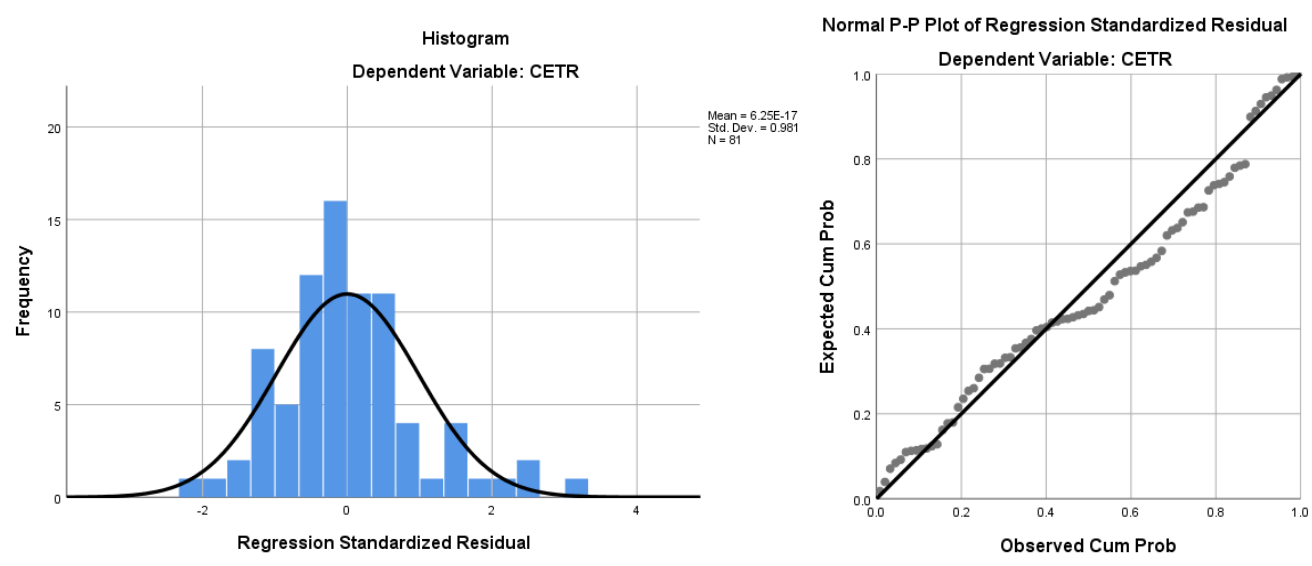

Gambar 2. Grafik Histogram Normalitas dan Normal Probability Plot

Berdasarkan Tabel 5, dapat dilihat bahwa nilai Kolmogorov-Smirnov adalah 0,098 dan nilai signifikansinya sebesar 0,051. Karena nilai signifikansinya lebih dari 0,05 maka $\mathrm{H} 0$ diterima sedangkan $\mathrm{Ha}$ normal yaitu berbentuk simetris tidak menceng ke kanan atau ke kiri.

Maka dari itu, dapat disimpulkan bahwa model regresi di dalam penelitian ini telah memenuhi asumsi normalitas. Selain itu, normal probability plot menunjukkan bahwa titik-titik menyebar berhimpit disekitar garis diagonal serta penyebarannya mengikuti arah garis diagonal. Hal ini menunjukkan bahwa residual data penelitian terdistribusi secara normal dan memenuhi asumsi normalitas.

Tabel 5. Hasil Uji Kolmogorov Smirnov

\begin{tabular}{llr}
\hline & & Unstandardized Residual \\
\hline N & & 81 \\
\hline Normal Parameters & Mean & 0,0000000 \\
\cline { 2 - 3 } & Std. Deviation & 0,11687046 \\
\hline \multirow{2}{*}{ Most Extreme Differences } & Absolute & 0,098 \\
\cline { 2 - 3 } & Positive & 0,098 \\
\cline { 2 - 3 } & Negative & $-0,055$ \\
\hline Test Statistics & & 0,098 \\
\hline Asymp. Sig (2-Tailed) & & $0,051^{\mathrm{c}}$ \\
\hline
\end{tabular}




\section{Uji Multikolonieritas}

Tabel 6. Hasil Uji Multikolonieritas

\begin{tabular}{llcc}
\multirow{2}{*}{ Model } & \multicolumn{2}{c}{ Collinearity } & Statistics \\
\cline { 2 - 3 } & & Tolerance & VIF \\
\hline 1 & CSRI & 1,000 & 1,000 \\
\cline { 2 - 3 } & LEV & 0,997 & 1,003 \\
\hline \multicolumn{2}{c}{ KM } & 0,997 & 1,003 \\
\hline
\end{tabular}

Berdasarkan Tabel 6, seluruh variabel independen mempunyai nilai Tolerance $\geq$ 0,10 atau nilai VIF hitung $\leq 10$. Maka dapat disimpulkan bahwa seluruh variabel independen di dalam penelitian ini tidak mengalami masalah multikolonieritas atau dengan kata lain bahwa antara pengungkapan corporate social responsibility, leverage, dan kepemilikan manajerial tidak saling berhubungan.

\section{Uji Autokorelasi}

Tabel 7. Hasil Uji Autokorelasi Model Durbin-Watson 1 2,006

Berdasarkan Tabel 7 , nilai Durbin Watson (D-W) adalah sebesar 2,006. Jumlah data (n) sebanyak 81 dan jumlah variabel independen $(\mathrm{k})$ sebanyak 3 . Berdasarkan tabel D-W $(\mathrm{n})=81$ dan $(\mathrm{k})=$ 3, maka batas bawah Durbin Watson (dL) sebesar 1,5632 dan batas atas Durbin Watson (dU) sebesar 1,7164. Apabila sudah mengetahui nilai batas bawah Durbin Watson (dL) dan batas atas Durbin Watson (dU) maka nilai Durbin Watson sebesar 2,006 dibandingkan dengan kedua nilai tersebut. Dengan melihat Tabel 5 dan tabel Durbin Watson, maka dapat diketahui bahwa nilai Durbin Watson sebesar 2,006 lebih besar dari batas atas durbin watson (dU) sebesar 1,7164 dan kurang dari 4-dU (4-1,5632) sebesar 2,4368 atau dapat dituliskan dengan $\mathrm{du}<\mathrm{dw}<4-\mathrm{dl}$. Hal ini menunjukkan bahwa H0 diterima yang artinya tidak terdapat autokorelasi pada model regresi.

\section{Uji Heterokedastisitas}

Berdasarkan Gambar 2, titik-titik menyebar secara acak dan tidak membuat pola tertentu. Hal ini berarti tidak terjadi heterokedastisitas karena pada grafik scatterplot terlihat bahwa titik-titik menyebar diatas dan dibawah angka 0 pada sumbu Y. Maka dari itu, dapat disimpulkan bahwa residual memiliki varians yang sama artinya tidak terjadi heterokedastisitas pada model regresi

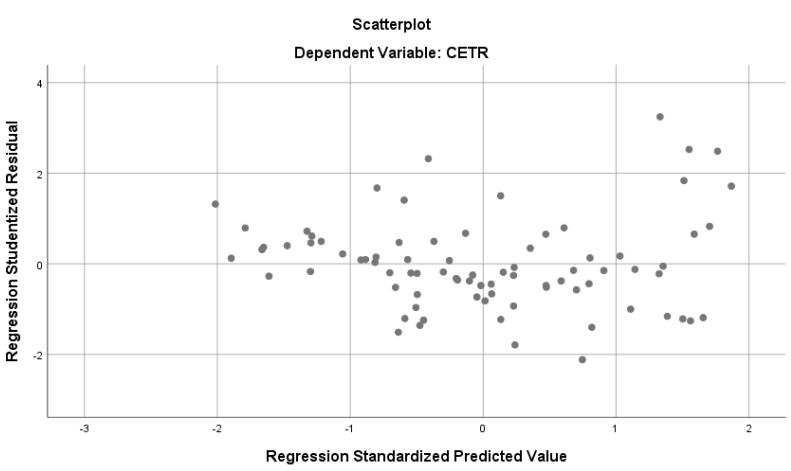

Gambar 3. Grafik Uji Heterokedastisitas

\section{Uji Koefisien Determinasi}

Hasil uji koefisien determinasi menunjukkan hasil sebagai berikut:

Tabel 8. Hasil Uji Koefisien Determinasi

\begin{tabular}{ccccc}
\hline Model & $R$ & $\begin{array}{c}R \\
\text { Square }\end{array}$ & $\begin{array}{c}\text { Adjusted } \\
R \text { Square }\end{array}$ & $\begin{array}{c}\text { Std. Error } \\
\text { of the } \\
\text { Estimate }\end{array}$ \\
\hline $\mathbf{1}$ & $0,335^{\mathrm{a}}$ & 0,112 & 0,078 & 0,1191254 \\
\hline
\end{tabular}

Berdasarkan Tabel 8, nilai Adjusted R Square (R2) sebesar 0,078. Hal ini menunjukkan bahwa sebesar $7,8 \%$ variasi agresivitas pajak dapat dijelaskan oleh pengungkapan corporate social responsibility, leverage, dan kepemilikan manajerial sedangkan sisanya yaitu sebesar 92,2\% dijelaskan oleh sebab-sebab lain diluar variabel penelitian.

\section{Uji Parsial (Uji t)}

Hasil uji parsial (uji t) menunjukkan hasil seperti Tabel 9. Hasil uji regresi linear berganda menunjukkan bahwa Pengungkapan Corporate Social Responsibility berpengaruh signifikan negatif terhadap CETR yang artinya Pengungkapan Corporate Social Responsibility berpengaruh signifikan positif terhadap Agresivitas Pajak. Hal ini dapat dilihat dari hasil uji hipotesis dimana 
$\mathrm{t}$ hitung > t tabel $(2,004>1,991)$ dengan nilai signifikansi kurang dari 0,05 (0,049 < $0,05)$. Dengan demikian, penelitian ini menerima hipotesis pertama (H1) yang menyatakan bahwa Pengungkapan Corporate Social Responsibility berpengaruh signifikan negatif terhadap Agresivitas Pajak namun hasilnya sebaliknya dimana semakin besar nilai indeks pengungkapan corporate social responsibility perusahaan atau semakin banyak pengungkapan corporate social responsibility yang dilakukan perusahaan maka akan meningkatkan tindakan agresivitas pajak yang dilakukan oleh perusahaan. Teori legitimasi menjelaskan bahwa tujuan organisasi harus selaras dengan nilai-nilai yang ada di dalam sebuah masyarakat (Dowling dan Pfefer, 1975). Dalam teori legitimasi, perusahaan akan senantiasa untuk mengungkapkan pertanggungjawaban sosialnya guna menunjukkan kepada publik bahwa perusahaan tidak hanya memperhatikan kepentingan perusahaan tetapi juga turut memperhatikan kepentingan publik.

Tabel 9. Hasil Uji Parsial (uji t)

\begin{tabular}{llrrrrr}
\hline & & \multicolumn{2}{c}{$\begin{array}{c}\text { Unstandardized } \\
\text { Coefficient }\end{array}$} & $\begin{array}{c}\text { Standardized } \\
\text { Coefficient }\end{array}$ & \multicolumn{1}{c}{ T } & \multirow{2}{*}{ Sig. } \\
\cline { 1 - 4 } Model & \multicolumn{1}{c}{ B } & Std. Error & \multicolumn{1}{c}{ Beta } & & \\
\hline & \multicolumn{1}{c}{ (Constant) } & 0,307 & 0,051 & & 6,062 & 0,000 \\
\hline CSRI & $-0,421$ & 0,210 & $-0,215$ & $-2,004$ & 0,049 \\
\hline LEV & 0,027 & 0,079 & 0,036 & 0,337 & 0,737 \\
\hline KM & 0,066 & 0,027 & 0,259 & 2,409 & 0,018 \\
\hline
\end{tabular}

a. Dependent Variable: CETR

Dalam melaksanakan pertanggungjawaban sosialnya, perusahaan akan mengeluarkan biaya-biaya yang tentu saja akan mengurangi laba sebelum pajak periode berjalan. Biaya-biaya yang dikeluarkan terkait dengan pertanggungjawaban sosial perusahaan ini dapat menjadi pengurang dari pajak penghasilan perusahaan.Undang-Undang Nomor 36 Tahun 2008 tentang Pajak Penghasilan pasal 6 ayat (1) menjelaskan bahwa besarnya penghasilan kena pajak bagi wajib pajak dalam negeri dan bentuk usaha tetap ditentukan berdasarkan penghasilan bruto dikurangi biaya untuk mendapatkan, menagih, dan memelihara penghasilan. Biaya-biaya ini juga termasuk biaya-biaya yang terkait dengan biaya-biaya yang dikeluarkan perusahaan untuk kegiatan tanggung jawab sosial (corporate social responsibility). Hal inilah yang mendorong perusahaan untuk melaksanakan kegiatan corporate social responsibility, dikarenakan biaya-biaya yang dikeluarkan dapat dijadikan pengurang dari pajak penghasilan perusahaan. Hasil penelitian ini didukung oleh penelitian yang dilakukan oleh Mutmahanah dan Septiani (2017).

Hasil uji regresi linear berganda menunjukkan bahwa Leverage tidak berpengaruh signifikan terhadap CETR yang artinya Leverage tidak berpengaruh signifikan terhadap Agresivitas Pajak. Hal ini dapat dilihat dari hasil uji hipotesis dimana $\mathrm{t}$ hitung $<\mathrm{t}$ tabel $(0,337<1,991)$ dengan nilai signifikansi lebih dari 0,05 $(0,737>0,05)$. Dengan demikian, penelitian ini menolak hipotesis kedua (H2) yang menyatakan bahwa Leverage berpengaruh signifikan negatif terhadap Agresivitas Pajak. Artinya, leverage bukanlah merupakan variabel dominan bagi perusahaan dalam melakukan agresivitas pajak penghasilan. Meskipun koefisien leverage bertanda positif terhadap CETR yang artinya bertanda negatif terhadap agresivitas pajak. Namun, nilai signifikansinya menunjukan bahwa leverage tidak berpengaruh signifikan terhadap agresivitas pajak yang artinya kebijakan pendanaan yang menggunakan 
hutang atau dana pihak ketiga untuk membiayai operasi perusahaan tidak mempengaruhi indikasi tindakan agresivitas pajak yang dilakukan perusahaan. Hal ini terjadi karena banyak perusahaan-perusahaan yang memiliki tingkat leverage tinggi tidak dapat memanfaatkan beban bunga yang ditanggungnya untuk mengurangi laba bersih, dimana perusahaan juga harus mempertahankan laba periode berjalan dalam kondisi yang baik. Salah satu contohnya adalah PT. Indofood Sukses Makmur Tbk, dimana perusahaan ini memiliki tingkat leverage yang besar dan cenderung menurun namun diikuti dengan laba sebelum pajak yang juga tinggi dan cenderung menurun. Namun, perusahaan yang memiliki nilai leverage yang besar belum tentu memiliki tingkat pembayaran pajak yang juga besar. Salah satunya adalah PT. Mayora Indah Tbk, dimana perusahaan tersebut memiliki nilai leverage yang besar dan cenderung menurun dengan diikuti nilai CETR yang kecil dan cenderung meningkat. Selain itu, dikarenakan hasil penelitian mengenai pengaruh leverage terhadap agesivitas pajak adalah tidak berpengaruh signifikan. Maka hasil penelitian ini tidak mendukung teori akuntansi positif yaitu political cost hypothesis dan debt covenant hypothesis. Artinya perusahaan yang memiliki nilai leverage yang besar belum bisa memanfaatkan keuntungan yang diperoleh dari beban bunga dan perusahaan yang memiliki nilai leverage yang besar tidak cenderung memiliki laba sebelum pajak yang besar. Hasil penelitian ini didukung oleh penelitian yang dilakukan oleh Adisamartha dan Noviari (2015), Hartadinata dan Tjaraka (2013), Tiaras dan Wijaya (2015), dan Windaswari dan Merkusiwati (2018).

Hasil uji regresi linear berganda menunjukkan bahwa kepemilikan manajerial berpengaruh signifikan positif terhadap CETR yang artinya Kepemilikan Manajerial berpengaruh signifikan negatif terhadap Agresivitas Pajak. Hal ini dapat dilihat dari hasil uji hipotesis dimana $\mathrm{t}$ hitung > $\mathrm{t}$ tabel $(2,409>1,991)$ dengan nilai signifikansi kurang dari 0,05 (0,018 > 0,05). Dengan demikian, penelitian ini menerima hipotesis ketiga $(\mathrm{H} 3)$ yang menyatakan bahwa Kepemilikan Manajerial berpengaruh signifikan negatif terhadap Agresivitas Pajak. Artinya dengan adanya kepemilikan manajerial di dalam perusahaan maka akan menurunkan tindakan agresivitas pajak yang dilakukan perusahaan. Dalam Agency Theory, dijelaskan bahwa pihak manajemen (agent) di dalam suatu perusahaan mempunyai tanggung jawab yang besar terhadap pemilik perusahaan (principle) sehingga manajemen dituntut untuk mengoptimalkan profit perusahaan yang nantinya akan dilaporkan di dalam laporan keuangan perusahaan. Adanya pemisahan hak dan tanggung jawab antara pihak manajer (agent) dengan pemilik perusahaan (principle) seringkali menimbulkan konflik yang dikenal dengan agency conflict. Menurut Jensen and Meckling (1976), kepemilikan manajerial merupakan salah satu cara yang dapat diterapkan untuk meminimalisir terjadinya agency conflict di dalam perusahaan. Dengan adanya kepemilikan manajerial di dalam perusahaan, pihak manajemen akan memiliki peran ganda yaitu sebagai agent dan principle. Hal ini akan membuat pihak manajemen untuk lebih berhati-hati dalam mengambil keputusan karena apabila keputusan yang diambil salah maka pihak manajemen juga akan ikut menanggung dampak yang timbul baik langsung maupun tidak langsung. Pihak manajemen pada perusahaan yang terdapat kepemilikan manajerial di dalam komposisi pemegang sahamnya akan cenderung lebih mempertimbangkan kelangsungan hidup perusahaan, salah satunya adalah melalui penciptaan laba perusahaan yang tentu saja akan berdampak terhadap kewajiban perpajakannya. Dengan demikian, perusahaan yang terdapat kepemilikan saham oleh pihak manajemen (agent) di 
dalam komposisi pemegang sahamnya akan cenderung untuk meningkatkan laba periode berjalan dikarenakan pihak manajemen akan mendapatkan manfaat baik langsung maupun tidak langsung atas prestasinya dan investasinya di dalam perusahaan. Laba periode berjalan yang besar akan berdampak pada pembayaran pajak yang juga besa, artinya dengan adanya kepemilikan manajerial di dalam perusahaan maka akan membuat perusahaan tidak agresif terhadap pajak. Hasil penelitian ini didukung dengan penelitian-penelitian yang dilakukan oleh Fadhila dkk (2017) dan Pramudito dan Sari (2015) yang menyatakan bahwa kepemilikan manajerial berpengaruh signifikan negatif terhadap agresivitas pajak.

\section{SIMPULAN}

Adapun kesimpulan yang diperoleh dari penelitian ini adalah sebagai berikut:

- Pengungkapan Corporate Social Responsibility berpengaruh signifikan negatif terhadap CETR. Artinya, semakin banyak pengungkapan corporate social responsibility yang dilakukan oleh perusahaan maka semakin meningkatkan agresivitas pajak penghasilan perusahaan. Hal ini terjadi karena biaya-biaya yang muncul untuk melaksanakan kegiatan corporate social responsibility dapat dialokasikan sebagai pengurang pembayaran pajak penghasilan perusahaan sebagaimana diatur dalam UndangUndang Nomor 36 Tahun 2008 tentang Pajak Penghasilan sehingga dapat digunakan oleh perusahaan sebagai salah satu cara untuk meminimalisir pajak penghasilan perusahaan.
Leverage tidak berpengaruh signifikan terhadap CETR. Di dalam penelitian ini, variabel leverage bukan merupakan variabel yang dominan bagi perusahaan untuk melakukan agresivitas pajak penghasilan. Hal ini terjadi karena perusahaan yang memiliki nilai leverage yang besar tidak mampu untuk memanfaatkan beban bunga yang ditanggungnya sebagai pengurang pajak, dimana perusahaan juga dituntut untuk mempertahankan laba periode berjalan. Meskipun demikian, perusahaan yang memiliki nilai leverage yang besar juga tidak cenderung diikuti dengan tingkat pembayaran pajak yang juga besar.

Kepemilikan manajerial berpengaruh signifikan positif terhadap CETR. Artinya, jika ada kepemilikan saham oleh pihak manajemen (agent) di dalam perusahaan maka akan menurunkan agresivitas pajak penghasilan perusahaan. Hal ini terjadi karena kepemilikan manajerial mendorong pihak manajemen di dalam perusahaan untuk mempertahankan kelangsungan hidup perusahaan, salah satunya adalah dengan penciptaan laba. Pihak manajemen cenderung menghindari risiko-risiko yang mengancam kelangsungan hidup perusahaan dikarenakan selain berperan sebagai pihak agent, mereka juga berperan sebagai pihak principal.

- Berdasarkan hasil pengujian koefisien determinasi (adjusted R2), diperoleh nilai adjusted R2 sebesar 0,078 atau $7,8 \%$ yang menunjukkan bahwa variabel Agresivitas Pajak dipengaruhi oleh Pengungkapan 
Corporate Social Responsibility,

Manajerial hanya sebesar 7,8\% dan sisanya yaitu sebesar 92,2\% dipengaruhi oleh variabel lain yang tidak digunakan dalam penelitian ini.

\section{DAFTAR PUSTAKA}

1. , Peraturan Pemerinah Republik Indonesia Nomor 46 Tahun 2013 tentang Pajak Penghasilan atas Penghasilan yang Diterima atau Diperoleh Wajib Pajak yang Memiliki Peredaran Bruto Tertentu.

2. Undang-Undang Republik Indonesia Nomor 28 Tahun 2007, Perubahan Ketiga Atas UndangUndang Republik Indonesia Nomor 6 Tahun 1983 tentang Ketentuan Umum dan Tata Cara Perpajakan.

3. Undang-Undang Republik Indonesia Nomor 36 Tahun 2008, Perubahan Keempat Atas Undang-Undang Republik Indonesia Nomor 7 Tahun 1983 tentang Pajak Penghasilan.

4.

Undang-Undang

Republik Indonesia Nomor 40 Tahun 2007 tentang Perseroan Terbatas.

5. Adisamartaha, I.B.P.F., dan Noviari, N., Pengaruh Likuiditas, Leverage, Intensitas Persediaan, dan Intensitas Aset Tetap pada Tingkat Agresivitas Wajib Pajak Badan, E-Jurnal Akuntansi Universitas Udayana, Volume XIII Nomor 3, hlm. 9731.000, 2015.

6. Andhari, P.A.S., dan Sukartha, I.M., Pengaruh Pengungkapan Corporate Social Responsibility, Profitabilitas, Inventory Intensity, Capital Intensity, dan Leverage pada Agresivitas Pajak, E-Jurnal Akuntansi Universitas Udayana, Volume XVIII Nomor 3, hlm. 2.115-2.142, 2017.

7. Atari, J., Pengaruh Kepemilikan Manajerial, Kepemilikan Institusional, dan Kebijakan Hutang Terhadap Tax Aggressive, JOM
Fekon, Volume III Nomor 1, hlm. 1.137-1.149, 2016.

8. Azheri, B., Corporate Social Responsibility dari Voluntary menjadi Mandatory, Jakarta: PT RajaGrafindo Persada, 2011.

9. Badan Pusat Statistik, Realisasi Penerimaan Negara (Milyar Rupiah) 2017-2018, diakses pada 10 September 2018, dari https://www.bps.go.id/statictable/200 9/02/24/1286/realisasi-penerimaannegara-milyar-rupiah-20072018.html, 2018.

10. Brigham, E.F. and Houston, J.F., Dasar-Dasar Manajemen Keuangan, Edisi 11, (Edward Tanujaya, Penerjemah), Jakarta: Salemba Empat, 2010.

11. Dharma, I.M.S., dan Ardiana, P.A., Pengaruh Leverage, Intensitas Aset Tetap, Ukuran Perusahaan, dan Koneksi Politik Terhadap Tax Avoidance, E-Jurnal Akuntansi Universitas Udayana, Volume XV Nomor 1, hlm. 584-613, 2016.

12. Direktorat Jenderal Pajak, Laporan Kinerja 2016 Direktorat Jenderal Pajak, Jakarta: Kementerian Keuangan Republik Indonesia.

13. Direktorat Penyusunan APBN dan Direktorat Jenderal Anggaran, Informasi APBN 2018, Jakarta: Kementerian Keuangan Republik Indonesia, 2017.

14. Dowling, J., and Pfeffer, J., Organitational Legitimacy: Social Values and Organizational Behaviour, The Pacific Sosiological Review, Volume XVIII Number 1, pp. 122-136, 1975.

15. Fadhila, N.S., Pratomo, D,. dan Yudowati, S.P., Pengaruh Kepemilikan Manajerial,Komisaris Independen, dan Komite Audit Terhadap Tax Avoidance, E-Jurnal Akuntansi Universitas Udayana, Volume XXI Nomor 3, hlm. 1.8031.820, 2017. 
16. Fadli, I., Pengaruh Likuiditas, Leverage, Komisaris Independen, Manajemen Laba, dan Kepemilikan Institusional Terhadap Agresivitas Pajak Perusahaan (Studi pada perusahaan manufaktur yang terdaftar di Bursa Efek Indonesia periode 2011-2013), JOM Fekon, Volume III Nomor 1, hlm. 1.2051.219, 2016.

17. Fahriani, M., dan Priyadi, M.P., Pengaruh Good Corporate Governance terhadap Tindakan Pajak Agresif pada Perusahaan Manufaktur, Jurnal Ilmu dan Riset Akuntansi, Volume V Nomor 7, hlm. 1-20, 2016.

18. Ghozali, I., Aplikasi Analisis Multivariate dengan Program IBM SPSS 25, Edisi 9, Semarang: Badan Penerbit Universitas Diponegoro, 2018.

19. Global Reporting Initiative, G4 Pedoman Pelaporan Keberlanjutan, Amsterdam: Global Reporting Initiative, 2013.

20. Hartadinata, O.S., dan Tjaraka, H., Analisis Pengaruh Kepemilikan Manajerial, Kebijakan Hutang, dan Ukuran Perusahaan terhadap Tax Agressiveness pada Perusahaan Manufaktur di Bursa Efek Indonesia Periode Tahun 2008-2010, Jurnal Ekonomi dan Bisnis, Volume XXIII Nomor 3, hlm. 48-59, 2013.

21. Hartarto, A., Kemenperin: Industri Manufaktur Penyumbang Pajak Terbesar, diakses pada 10 September 2018 , dari https://ekonomi.kompas.com/read/20 18/01/09/211727326/kemenperinindustri-manufaktur-penyumbangpajak-terbesar, 2018.

22. Jensen, M.C., and Meckling, W.H., Theory of the Firm: Managerial Behavior, Agency Costs, and Ownership Structure, Journal of Financial Economics, Volume III, pp. 305-360, 1976.
23. Jessica, dan Toly, A.A., Pengaruh Pengungkapan Corporate Social Responsibility Terhadap Agresivitas Pajak, Tax \& Accounting Review, Volume IV Nomor 1, hlm. 1-16, 2014.

24. Kementerian Keuangan Republik Indonesia, Media Keuangan Transparansi Informasi Kebijakan Fiskal, Edisi Maret 2017, Jakarta: Kementerian Keuangan Republik Indonesia, 2017.

25. Keown, A.J., Martin, J.D., and Petty, J.W., Foundations of Finance, 9th Edition, Harlow: Pearson Education Limited, 2017.

26. Lanis, R. and Richardson, G., Corporate Social Responsibility And Tax Agressiveness: An Empirical Analysis, J. Account Public Policy, Volume XXXI, pp. 86-108, 2012.

27. Mayangsari, C., Pengaruh Kompensasi Eksekutif, Kepemilikan Saham Eksekutif, Preferensi Risiko Eksekutif, dan Leverage Terhadap Penghindaran Pajak, JOM Fekon, Volume II Nomor 2, hlm.1-15, 2015.

28. Mumtahanah, S.N., dan Septiani, A., Pengaruh Pengungkapan Corporate Social Responsibility Terhadap Agresivitas Pajak dengan Moderasi Kepemilikan Saham oleh Keluarga, Diponegoro Journal of Accounting, Volume VI Nomor 4, hlm. 1-13, 2017.

29. Novitasari, S., Pengaruh Manajemen Laba, Corporate Governance, dan Intensitas Modal Terhadap Agresivitas Pajak Perusahaan, JOM Fekon, Volume IV Nomor 1, hlm. 1.901-1.914, 2017.

30. Pramudito, B.W., dan Sari, M.M.R., Pengaruh Konservatisme Akuntansi, Kepemilikan Manajerial, dan Ukuran Dewan Komisaris Terhadap Tax Avoidance, Volume XIII Nomor 3, hlm. 705-722, 2015.

31. Prasetyo, E., dan Pramuka, B.A., Pengaruh Kepemilikan Institusional, Kepemilkan Manajerial, dan Proporsi Dewan Komisaris Independen Terhadap Tax Avoidance, Jurnal 
Ekonomi, Bisnis, dan Akuntansi (JEBA), Volume XX Nomor 2, hlm. 1-15, 2018.

32. Prasista, P.M., dan Setiawan, E., Pengaruh Profitabilitas dan Pengungkapan Corporate Social Responsibility Terhadap Agresivitas Pajak Penghasilan Wajib Pajak Badan, E-Jurnal Akuntansi Universitas Udayana, Volume XVII Nomor 3, hlm. 2.120-2.144, 2016.

33. Ratmono, D. dan Sagala, W.M.,, Analisis Pengaruh Pengungkapan Corporate Social Responsibility Terhadap Agresivitas Pajak, Diponegoro Journal of Accounting, Volume IV Nomor 3, hlm. 1-9, 2015.

34. Rengganis, R.R.M.Y.D., dan Putri, I.G.A.M.A.D., Pengaruh Corporate Governance dan Pengungkapan Corporate Social Responsibility Terhadap Agresivitas Pajak, E-Jurnal Akuntansi Universitas Udayana, Volume XXIV Nomor 2, hlm. 871898, 2018.

35. Rohman, A. dan Pradnyadari, I.D.A.I., Pengaruh Pengungkapan Corporates Social Responsibility Terhadap Agresivitas Pajak, Diponegoro Journal of Accounting, Volume IV Nomor 2, hlm. 1-9, 2015.

36. Ross, S.A., Westerfield, R.W., Jordan, B.D., Lim, J., and Tan, R., Fundamental of Corporate Finance, Asian Global Edition, 2nd Edition, New York: McGraw Hill Education, 2016.

37. Scott, W.R., Financial Accounting Theory, 3rd Edition. New Jersey: Pearson Canada Inc, 2003.

38. Scott, W.R., Financial Accounting Theory, 6th Edition. Ontario: Pearson Canada Inc, 2012.

39. Sianipar, E., Coca-Cola Diduga Akali Setoran Pajak, diakses pada 10 September 2018, dari https://ekonomi.kompas.com/read/20 14/06/13/1135319/CocaCola.Diduga. Akali.Setoran.Pajak, 2014.
40. Sumarsan, T., Tax Review dan Strategi Perencanaan Pajak, Jakarta: PT. Indeks, 2012.

41. Suyanto, K.D., dan Supramono., Pengaruh Likuiditas, Leverage, Komisaris Independen,dan Manajemen Laba Terhadap Agresivitas Pajak Perusahaan, Jurnal Keuangan dan Perbankan, Volume XVI Nomor 2, hlm. 167-177, 2012.

42. Tiaras, I., dan Wijaya, H., Pengaruh Likuiditas, Leverage, Manajemen Laba, Komisaris Independen, dan Ukuran Perusahaan Terhadap Agresivitas Pajak, Jurnal Akuntansi, Volume XIX Nomor 3, hlm. 380-397, 2015.

43. Windaswari, K.A., dan Merkusiwati, N.K.L.A., Pengaruh Koneksi Politik, Capital Intensity, Profitabilitas, Leverage, dan Ukuran Perusahaan pada Agresivitas Pajak, E-Jurnal Akuntansi Universitas Udayana, Volume XXIII Nomor 3, hlm. 19802008, 2018. 